\title{
The Application of Modification E-Learning and Collaborative Learning Methods in the Public Health Nutrition Basic Course
}

\author{
Azrimaidaliza ${ }^{1, *}$ Resmiati $^{2,}$ Welly Famelia ${ }^{2}$ Idral Purnakarya ${ }^{1,}$ Firdaus ${ }^{1}$ \\ ${ }^{1}$ Nutrition Science Study Program, Faculty of Public Health, Andalas University \\ ${ }^{2}$ Public Health Science Study Program, Faculty of Public Health, Andalas University \\ *Correspondence author. E-mail azrimaidaliza@ph.unand.ac.id
}

\begin{abstract}
In this 4.0 era, the use of internet in the learning process in higher institutions cannot be avoided, and the number of it increases rapidly since the COVID-19 pandemic. This situation makes face to face learning difficult or even impossible to be carried out. Therefore, universities in Indonesia have started to apply learning methods that get along with internet. This study was classroom action research that applied the modification of collaborative learning and elearning method in the Public Health Nutrition Basic Course which impacted to student's mark. The samples were 161 students who took Public Health Nutrition Basic Course and 6 lecturers of Nutrition Study Program. Questionnaire that has been validated was the instrument used in this research. The data were presented descriptively and using percentage to describe the result of the study. The research showed that the ap

plication of collaborative learning and interactive e-learning method can effectively improve students' learning outcomes. The students' final semester test score is higher comparing to the score of mid term test. It is expected that these methods can be applied in the following semester and the institution should facilitate the students with free internet package to support the e-learning method.
\end{abstract}

Keywords: Learning methods, collaborative learning, e-learning, test scores

\section{INTRODUCTION}

Industrial revolution 4.0 drives higher education institutions (universities) to embrace information technology in learning activities to produce competitive graduates for the workplace. Face-to-face learning methods (conventional method) have begun to shift towards distance learning that allows more flexible, open, and accessible learning at any time. The corona virus disease or COVID-19 pandemic prompts the utilization of interactive learning media such as elearning for distance learning purposes. This media is one of the methods of distance learning between teachers and students using electronic media and internet information technology [1].

Andalas University, especially the Faculty of Public Health is one of the faculties that has implemented the use of media-based learning or e- learning. Unfortunately, it

has not been implemented maximally in the learning activities, including in the Public Health Nutrition Basic Course. This course is offered in semester 2 at the Public Health Study
Program (IKM Study Program) of Andalas University and it is a compulsory course. The description of this course is to discuss the development history and scope of nutrition science, grouping of nutrients and their respective roles in physiological functions of the body, sources of nutrients in food, and the needs of each nutrient due to deficiency and excess nutrients. Besides that, it also discusses the process of digestion, absorption and metabolism of food in the body and groups that are vulnerable to nutritional problems.

From this course, one of the competences that must be achieved by the students is they are able to explain nutritious food and how the role of these nutrients for the human body and the risks experienced when underconsumption and over-consumption of certain nutrients. So hopefully later when the public health faculty graduates work in health institutions, they can develop health programs to address public health problems or nutritional problems. They are also expected to be able to understand vulnerable groups and their nutritional needs through the use of local foodstuffs.

In this course, the teaching learning materials were in the form of power points. Students-Centred Learning 
approach and contextual learning method were implemented. Mostly, in the learning process, the students were assigned in groups to discuss a topic and work on group assignments. During the group activities, they searched for information from each other, solved problems, and developed a product or result. Each member gave contribution such as information, experiences, ideas, attitudes, opinions, abilities, and skills possessed to improve the understanding of all members. From the discussion at the group level, the group was asked to present it in class with power point media or modified into a video playback. Each group discussed different topics which were based on the syllabus. At the end of the course meeting, each group was asked to prepare a paper from the presentation assignment completed with the references.

The students' learning outcomes were measured through assignment presentations, examinations and attitude assessments during the learning process. From the results of the presentation assessment, it showed that not all students were involved in discussion activities. Then from the results of the mid test and final semester test, so far it showed varying grades (about $15 \%$ have $\mathrm{C}$ and $\mathrm{D}$ grades). Therefore it is necessary to develop more interactive learning so that all students will involve in the learning process and to facilitate the students to achieve the learning outcomes effectively.

The learning system recently developed is OutcomeBased Education (OBE). The curriculum is then developed by the study program by referring to OBE. Thus, it is expected that specified learning outcome can be achieved. The learning process is more on students centred, or known as Students Centered Learning (SCL). This learning provides opportunities for students to develop and carry out projects independently. In the OBE learning system, learning outcomes or achievements are identified first then planning learning methods and assessments are adjusted according to the outcomes [24].

To support OBE, the modification of collaborative learning and interactive e-learning is developed, and it is applied in the Public Health Nutrition Basic Course. This course is chosen since the learning outcome has not been maximally achieved. It is expected that the development of these methods can improve the atmosphere of learning process, improve the students' grades, achieve the learning outcomes, and enhance the students' competence through the revisions of current syllabus in Public Health Study Program, Faculty of Public Health.

\section{METHOD}

This was a descriptive research categorized as class action research. This research has the aim to analyze the implementation of the modification of collaborative learning and e-learning in the Public Health Nutrition Basic Course. This research was conducted after mid semester of the course from March until June 2020. The samples were 161 students who have taken Basic Public Health Nutrition Science course and 6 lecturers who are the lecturers in nutrition science study program.

The modification of the collaborative learning method and interactive e-learning in the Public Health Nutrition Basic Course was applied after mid-semester. This method is prepared by lecturers in the form of individual and group assignments, then optimally utilizes e-learning media for uploading assignments, materials or power point that must be understood by students, online quizzes, and paper project which is collected at the end of the semester. Online meeting is also used in learning process to present the group assignments and as media to discuss beside using e- learning.

The Evaluation of application the modification of collaborative learning methods and interactive elearning in the Public Health Nutrition Basic Course is known by comparing the scores obtained by students in the Final Semester Test (UAS) with the Mid Semester Test (UTS). In addition, researchers used a validated questionnaire to find out the opinions of students regarding; (1) Activities at the beginning of learning, (2) Implementation of learning, specifically the application of modification of collaborative learning and interactive e-learning method, and 3) Appropriateness of learning content in the Public Health Nutrition Basic Course. Each question has assessment criteria, namely (1) Unsatisfactory, (2) Poor, (3) Average, (4) Good, and (4) Excellent. Besides, the questionnaire was also distributed to the lecturers to find out their obstacles during the implementation of the modified and to ask their suggestion or input for improving the learning in the following semester. The data was collected through an online survey using internet or handphone.

The data of this research were analyzed using computer programs. The frequency distribution or percentage of each question related to students' opinions regarding the application of collaborative learning and interactive e-learning methods was implemented.

\section{RESULTS}

The data collected are the learning process and the results of learning. The learning process includes activities at the beginning of course, implementation of learning, and learning conformity. The learning process was evaluated based on students' assessment and lecturers' assessment outside from the team teaching of Public Health Nutrition Basic Course. While for the result of learning to know the effectiveness of modification collaborative and an interactive e-learning methods in Public Health Nutrition Basic Course, it was assessed from Mid Semester Test (UTS) and Final Semester Test (UAS) scores. 


\subsection{Learning process evaluation based on Student Assessment}

\subsubsection{Description of activities at the beginning of learning}

Students' assessment related to activities at the beginning of learning consists of the lecturer's explanation of syllabus, learning objectives, learning materials, and learning evaluation. From the result, it can be seen that most students get good grades $(64.6 \%)$ at the beginning of learning (Figure 1). Nearly most students get clear information from lecturers related to the syllabus for the Public Health Nutrition Basic Course.

\subsubsection{Description of the learning implementation}

Students' assessment related to the implementation of learning consists of lecturers' efforts to focus their attention on participating in learning, the presentation of learning that is easily accepted and understood, motivating students to be more active and do their tasks independently or in groups. In addition to the implementation of learning, students were asked to assess the efforts of lecturers in terms of active students participation in learning, the presence of students' learning interactions, the use of varied learning methods, the effort to provide explanations of students' questions and examples that are relevant to the material.

Based on the results, the learning implementation has been going well, with almost $60 \%$ in the good category $(51.0 \%)$ and excellent (8.3\%) (Figure 1). Then around $38.5 \%$ of students gave an assessment that the implementation of learning was in the average category.

Specifically, in the implementation of learning, students are asked about the application of learning methods using interactive e-learning after mid-semester modified with collaborative learning. Students evaluate that application of learning methods using collaborative learning and interactive e-learning has been going well. It is identified that the student's assessments of the method are $43.8 \%$ which is in the good category, 2,1\% in excellent category, and $45.8 \%$ in average category.

\subsubsection{Description of Learning Conformity}

Students' assessment of the suitability of learning consists of the suitability of learning materials with the syllabus and the suitability and relevance of quizzes, assignments, Midterm Test (UTS) and Final Semester Test (UAS) with lecture material.

The result shows that most of the students assess the learning that is carried out in accordance with the syllabus and evaluation of learning through quizzes, midterms and final test conducted $(85.5 \%)$. Then $14.6 \%$ of students stated that it was quite appropriate (14.6\%) learning activities were in accordance with the syllabus and evaluations provided in quizzes, midterm and final test (Figure 1).

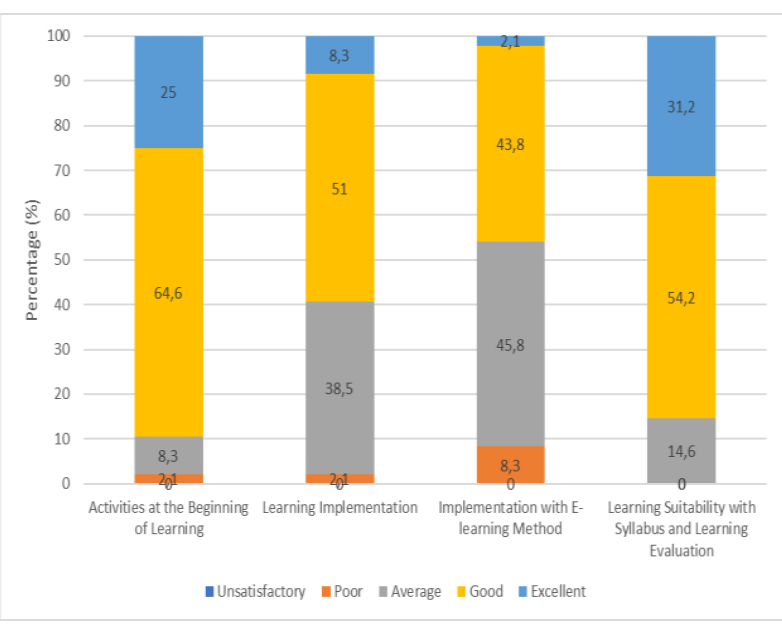

Figure 1. Student Assessment of Learning the Public Health Nutrition Basic Course.

\subsection{Learning process evaluation based on Lecturer Assessment}

Questionnaire was given to lecturers to know their obstacles during the application of the e-learning method modified with collaborative learning after mid- semester. The lecturers were also asked to give suggestions and input related to that method for the learning improvement in the following semester.

From the questionnaire analysis, it was found out that most students are having difficulty in accessing the internet and this affects the task performance. It was also found out that the students were having difficulty to concentrate or focus while studying at home since they also have to do the household. While from the lecturers' side, the obstacle faced in the learning process is that elearning media is not fully understood by the lecturer in terms of features that can be utilized. Thus, the learning process with the use of the media has not been maximally used.

Furthermore, suggestions that are given by the lecturers related to the learning process using this method are providing internet facilities for the students especially the ones who are having difficulty in buying the data package because of economic problems. Then It is also suggested the lecturers to be more creative in creating learning video for e-learning media. Therefore, the students will be more motivated in joining the learning activities. 


\subsection{Result of the Implementation of Modified Collaborative learning and Interactive $E$ - learning Methods in the Public Health Nutrition Basic Course}

The evaluation of learning outcomes after applying the collaborative learning method that was modified with e-learning media in the Public Health Nutrition Basic Course is known through increasing grades by comparing the score of the Midterm Test (UTS) with the score of the Final Semester Test (UAS). Students' learning outcomes through the test can be seen in the following Figure 2;

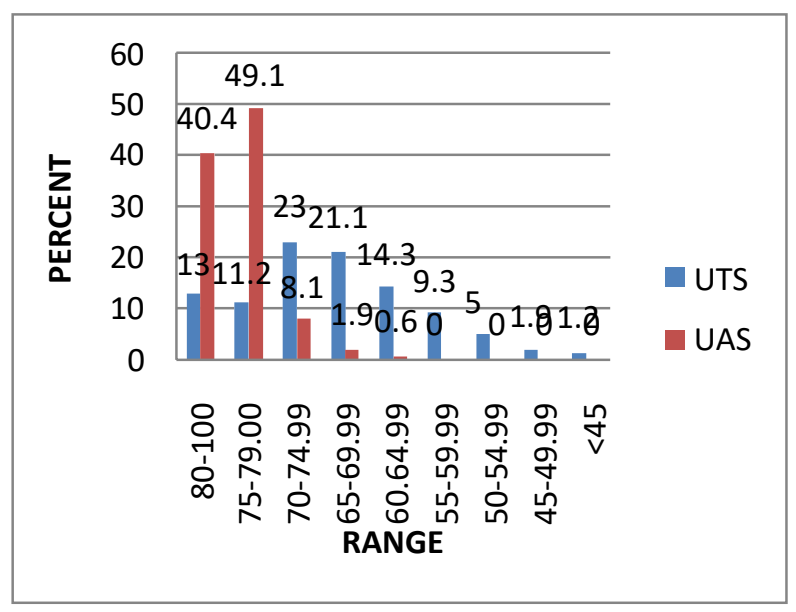

Figure 2. Results of Learning Evaluation in the Public Health Nutrition Basic Course

Based on the evaluation, it is known that the score of the students in Final Semester Test is higher than the score of the students in Midterm Test. The UAS score is better than the UTS score, in which the category scores above 75 are more in the UAS score. In addition, the lowest score in midterm test was in the category $<45$ and the lowest score in final semester test was in the category 60-64,99.

\section{DISCUSSION}

Collaborative learning is an educational approach that involves a group of learners or students who work together in overcoming problems, completing assignments or creating a product [5]. In Public Health Nutrition Basic course, the collaborative learning methods are combined with interactive e-learning. Elearning is carried out through the use of e-learning media, uploading of material, students' assignment in individual and group. Based on the results of evaluations through tests, it can be seen the increase in the percentage of students with a range of score of 75 until $<80$ or category A- at the time of the UAS compared to the UTS was $49.1 \%$ versus $11.2 \%$ UAS score was the result of the implementation of modified collaborative learning and interactive e-learning methods.
The data show that there weren't any students $(0 \%)$ who got score below 60 in final semester test. Meanwhile during midterm semester, there were around $17 \%$ students who got score below 60. Thus, it is very clear that this method is effectively improve the students in learning. In addition, there is the increase in student creativity in the form of learning outcomes, especially in making videos containing learning materials that are uploaded on YouTube media.

Development in learning activities must be carried out in this pandemic situation. Most learning activities have turn into online learning. In Indonesia, this online learning is supported by the Ministry of Education and Culture. The learning method with the modification of collaborative learning and interactive e-learning is very suitable with the pandemic conditions. This method makes the students can study anywhere and anytime in accessing the course through individual or in groups. They will have more time learning independently to search for learning material and with their creativity they will be able to produce video as their outcome. Since it is independent learning, the students can discuss with their friends in understanding the material and do group assignments through the internet or telephone media. Some benefits using collaborative learning are developing higher level thinking, increasing the student responsibility, understanding of diverse perspectives [6], and increasing the students' engagement outside the classroom [7]. However, there was evidence that successful collaboration in face-to-face situation was possible in online learning environment. Then, it should be supported by student's familiarity and the ease of use of interface to produce a more effective learning system [8].

On the other hand, the use of e-learning media also requires lecturers' skills in preparing more innovative and interesting learning materials as well as the ability to utilize the features available in e-learning media. For this reason, it is necessary to hold training for lecturers in the use of e-learning so that learning is more interesting and can fulfill subject learning outcomes [1,9].

Interactive e-learning methods in Public Health Faculty, University of Andalas (FKM Unand) has been introduced to lecturers in the last 2 years but has not been fully utilized by all lecturers. The methods have been built each semester by the FKM Unand ICT team precisely before the start of semester learning. Thus, the lecturers can take advantage of the method in the learning process especially during the COVID-19 pandemic recommended by the University. The condition of the COVID-19 pandemic allows for more optimal use of this media in learning activities. Lecturers can utilize this media in the process of transferring knowledge to students, designing learning activities, materials that must be studied by students and assignments that students must do can be uploaded in this media. Besides that, 
learning the discussion activities can also be carried out using this media [10].

From this research, the obstacles in the implementation of this method are also found, especially in the use of e-learning. Based on the results of the questionnaire regarding learning activities provided to lecturers, it is known that this media requires good internet access, while the number of students taking this course is quite a lot (more than 100 people) and students live in various regions not only within the city of Padang but also outside the Province of West Sumatra even in suburb areas. This was also revealed from the submission of almost all students through a questionnaire stating that the obstacle that mostly affected the use of e-learning media was an unstable internet network, especially for students living in distant areas.

It is hoped that in the following semester, e-learning is used more actively through virtual face-to-face media, telephone, or whats app or e-mail applications. Besides that, it is expected that lecturers prepare learning videos in each learning session that support the students who are learning independently or in a group discussion.

\section{CONCLUSION}

The application of collaborative learning and interactive e-learning method can effectively improve students' mark, creativity in video task and quality of articles task. It suggests to train the lecturer in using features of e-learning media so it results online learning more interactive and interesting. Beside the strategy is required in easy of access internet for the students during learning activities.

\section{AUTHORS' CONTRIBUTIONS}

All authors contributed in planning the study. Azrimaidaliza, Idral Purnakarya and Firdaus were involved in developing the learning methods and applying that methods after mid semester. All authors discussed the results and contributed to the final manuscript.

\section{ACKNOWLEDGMENTS}

We would like to thank LP3M of Andalas university for providing assistance in the form of Class Action Research Grants, so that this research can be carried out well.

\section{REFERENCES}

[1] Hasibuan, MS. System e-learning dengan pendekatan evaluasi pembelajaran. Seminar Nasional Aplikasi Teknologi Informasi 2009 (SNATI 2009).Yogyakarta, 20 Juni 2009. 2012.

[2] Wahyudi, Haris and Ignatius Wibowo, Agung I. Inovasi dan Implementasi Model Pembelajaran Berorientasi Luaran (Outcome-Based Education,
OBE) dan Washington Accord di Program Studi Teknik Mesin Universitas Mercu Buana. Jurnal Teknik Mesin: Vol. 07, No. 2, Juni 2018.

[3] Direktorat Penjaminan Mutu, Ditjen Belmawa Kemenristekdikti. Pendidikan Berbasis Capaian Pembelajaran (Outcome-based Education/OB). 2018.

[4] Arifin, Pepen. Outcome Based education. Disampaikan pada saat Sosialisasi Akreditasi Internasional, Universitas Sumatera Utara. 2019.

[5] Laal, Marjan dan Ghodsi, Seyed Mohammad. Benefits of collaborative learning. Procedia - Social and Behavioral Sciences, Volume 31, 2012, Pages 486 490

https://www.sciencedirect.com/science/article/pii/S 1877042811030205

[6] Ritu Chandra. Collaborative Learning for Educational Achievement. Journal of Research \& Method in Education. Volume 5, Issue 2 Ver. III (Mar - Apr. 2015).

[7] Rosario Hernandez. Collaborative Learning: Increasing Students' Engagement Outside the Classroom. US-China Education Review A 9 (2012) 804-812.

[8] David D. Curtis and Michael J. Lawson, 2001. Exploring Collaborative Online Learning. JALN Volume 5, Issue 1 - February 2001

[9] Ilker Yengina, Dilek Karahocab, Adem Karahocab, Ahmet Yücelb. Roles of teachers in e-learning: How to engage students \& how to get free e- learning and the future. Procedia Social and Behavioral Sciences 2 (2010) 5775-5787. Diakses pada https://pdf.sciencedirectassets.com.

[10] Rahmawati, Fitria 2016. E-Learning Implementation: Its Opportunities and Drawbacks Perceived by EFL Students. Journal of Foreign Language and Teaching Learning. Volume 1 No. 1. https://journal.umy.ac.id/index.php/FTL/article/vie $\underline{w} / 2022$

[11] S. Bensalem, M. Bogza, A. Legay, T.H. Nguyen, J. Sifakis, R. Yan, Incremental component-based construction and verification using invariants, in: Proceedings of the Conference on Formal Methods in Computer Aided Design (FMCAD), IEEE Press, Piscataway, NJ, 2010, pp. 257-256.

[12] H. Barringer, C.S. Pasareanu, D. Giannakopolou, Proof rules for automated compositional verification through learning, in Proc. of the 2nd International Workshop on Specification and Verification of Component Based Systems, 2003.

[13] M.G. Bobaru, C.S. Pasareanu, D. Giannakopoulou, Automated assume-guarantee reasoning by 
abstraction refinement, in: A. Gupta, S. Malik (Eds.),

Proceedings of the Computer Aided Verification,
Springer, Berlin, Heidelberg, 2008, pp. 135-148.

DOI: https://doi.org/10.1007/978-3540-70545-1_ 